\title{
Adult T-cell leukemia: a review of epidemiological evidence
}

\author{
Masako Iwanaga ${ }^{1}{ }^{*}$, Toshiki Watanabe $^{2}$ and Kazunari Yamaguchi ${ }^{3}$ \\ ${ }^{1}$ Graduate School of Public Health, Teikyo University, Tokyo, Japan \\ ${ }^{2}$ Graduate School of Frontier Sciences, The University of Tokyo, Tokyo, Japan \\ ${ }^{3}$ Department of Safety Research on Blood and Biologics, National Institute of Infectious Diseases, Tokyo, Japan
}

\section{Edited by:}

Renaud Mahieux, Ecole Normale Superieure de Lyon, France

Reviewed by:

Mirdad Kazanji, Institut Pasteur. France

Ali Bazarbachi, American University of Beirut, Lebanon

\section{${ }^{*}$ Correspondence}

Masako Iwanaga, Graduate School of Public Health, Teikyo University, 2-11-1 Kaga, Itabashi, Tokyo 173-8605,

Japan.

e-mail:masakoiwng@gmail.com

Adult T-cell leukemia (ATL) is an aggressive T-cell malignancy caused by human T-cell leukemia virus type I (HTLV-1) infection and often occurs in HTLV-1-endemic areas, such as southwestern Japan, the Caribbean islands, Central and South America, Intertropical Africa, and Middle East. To date, many epidemiological studies have been conducted to investigate the incidence of ATL among general population or HTLV-1 carriers and to identify a variety of laboratory, molecular, and host-specific markers to be possible predictive factors for developing ATL because HTLV-1 infection alone is not sufficient to develop ATL. This literature review focuses on the epidemiology of ATL and the risk factors for the development of ATL from HTLV-1 carriers, while keeping information on the epidemiology of HTLV-1 to a minimum. The main lines of epidemiological evidence are: (1) ATL occurs mostly in adults, at least 20-30 years after the HTLV-1 infection, (2) age at onset differs across geographic areas: the average age in the Central and South America (around 40 years old) is younger than that in Japan (around 60 years old), (3) ATL occurs in those infected in childhood, but seldom occurs in those infected in adulthood, (4) male carriers have about a three- to fivefold higher risk of developing ATL than female, (5) the estimated lifetime risk of developing ATL in HTLV-1 carriers is $6-7 \%$ for men and $2-3 \%$ for women in Japan, (6) a low anti-Tax reactivity, a high soluble interleukin-2 receptor level, a high anti-HTLV-1 titer, and high levels of circulating abnormal lymphocytes and white blood cell count are accepted risk factors for the development of ATL, and (7) a higher proviral load (more than 4 copies/100 peripheral blood mononuclear cells) is an independent risk factor for progression of ATL. Nevertheless, the current epidemiological evidence is insufficient to fully understand the oncogenesis of ATL. Further well-designed epidemiological studies are needed.

\section{Keywords: adult T-cell leukemia, ATL, epidemiology, human T-cell leukemia virus type I, HTLV-1}

\section{INTRODUCTION}

Adult T-cell leukemia (ATL) was first reported as a distinct clinical entity in Japan in 1977 (Takatsuki et al., 1977; Uchiyama et al., 1977). The clustering of patients in the southwestern part of Japan propelled Japanese investigators to the interest that the disease could be virally induced. Subsequently, human T-cell leukemia virus type I (HTLV-1) was discovered as the causative virus for ATL (Poiesz et al., 1980; Yoshida et al., 1982). The discoveries of ATL and HTLV-1 ushered in the development of virology, oncology, molecular biology, epidemiology, and other fields of medicine.

The etiological association of HTLV-1 with ATL was established on the basis of the following findings: (1) all patients with ATL have antibodies against HTLV-1 (Hinuma et al., 1981; Hinuma et al., 1982), (2) geographical areas of high incidence of ATL patients correspond closely with those of high incidence of HTLV-1 carriers (The T- and B-Cell Malignancy Study Group, 1985), (3) HTLV-1 immortalizes human CD4 T cells in vitro (Hattori et al., 1981), and (4) monoclonal integration of HTLV-1 proviral DNA was demonstrated in ATL cells (Yamaguchi et al., 1984). Subsequently, the Japanese Lymphoma Study Group proposed the first diagnostic criteria for ATL in 1991, and the disease was classified into four clinical subtypes; acute, lymphoma, chronic, and smoldering (Shimoyama, 1991).

ATL patients have been reported mainly from HTLV-1-endemic areas. The global geographical distribution of HTLV-1 seropositive individuals has been well documented (Proietti et al., 2005). Areas with seroprevalence of more than $2 \%$ are recognized as high endemic regions (Gessain, 1996). The main endemic areas are Japan, the Caribbean islands, Central and South America, Central and South Africa, a part of the Middle East and Melanesia, and Aboriginal regions in Australia (IARC, 1996). Moreover, regional clustering of virus positivity and high incidence of ATL has been detected even within the endemic areas. The prevalence of HTLV1 carriers in Europe, North America, China, and Korea is low (Proietti et al., 2005).

This literature review focuses on the epidemiology of ATL and the risk factors for the development of ATL from HTLV-1 carriers with asymptomatic status, while keeping information on the epidemiology of HTLV-1 to a minimum. A variety of study designs and settings, e.g., case series, nation wide surveys, and regional population-based studies using cancer registries were reported to assess incidence, prevalence, and other epidemiological 
information on ATL from many countries, mostly from Japan. However, there have been few prospective cohort studies to assess reliable incidence rate of ATL. Readers should keep in mind that all epidemiological studies have individual limitations in the case accumulation and the population setting.

\section{INCIDENCE AND PREVALENCE JAPAN}

In Japan, approximately one million individuals are carriers of HTLV-1 (Tajima, 1990; Satake et al., 2012). Both HTLV-1 and ATL have been shown to be endemic in southwest districts (Kyushu and Shikoku Islands; Tajima, 1990; Satake et al., 2012). Several epidemiological studies have been conducted to estimate annual incidence of ATL in HTLV-1 carriers or general population, but the exact annual incidence of ATL is still unclear. Most of the studies estimated the incidence of ATL just by merging the number of cases of ATL in one population to the number of people in another population such as demographic statistics, blood donors positive for HTLV-1, or an existing group of HTLV-1 carriers. Few prospective studies were conducted (Table 1).

Adult T-cell leukemia accounts for $51-59 \%$ of non-Hodgkin lymphoma (NHL) in HTLV-1 endemic areas in the Kyushu district, southwest Japan (Arisawa et al., 2000; Ohshima et al., 2002), which was extremely higher than that of nationwide data reporting that ATL accounts for 7.5\% of all lymphomas (Lymphoma Study Group of Japanese Pathologists, 2000).

\section{Annual mortality of ATL}

Approximately 1,000 people die of ATL each year in Japan according to Japanese vital statistics data for 1998-2008 (Portal Site of Official Statistics of Japan, 2012; Figure 1). This indicates that infection with HTLV-1 was associated with approximately 1,000 deaths from ATL annually, with clustering in people aged over 50 years (Ikeda et al., 2012).

\section{Annual incidence of ATL in nationwide studies}

In the first nationwide hospital-based survey, 657 new cases of ATL were accumulated during 1986-1987, estimating the annual number of ATL in Japan to be approximately 700 cases (Tajima, 1990; Shimoyama, 1991). The new nationwide hospital-based survey was conducted recently, in which a total of 910 new cases of ATL were accumulated during 2006-2007, estimating the annual number of ATL in Japan to be approximately 1,000 cases (Yamada et al., 2011). In the new survey, two new findings were revealed in contrast to the first nationwide study. First, the age at diagnosis increased from a mean age of 52.7 years in the previous survey to 66.0 years in the new survey (Figure 2). Second, there were differences in the proportion of subtypes; the acute subtype accounted for the highest percentage $(60.2 \%)$, followed by the lymphoma subtype $(23.7 \%)$ in the previous survey, however, the percentage of the lymphoma subtype increased to $34.8 \%$, contrary to the decrease in the acute subtype to be $46.7 \%$ in the new study. However, Takezaki et al. (1997) suggested that the annual incidence of ATL based on the nationwide hospital-based survey could be underestimated because approximately $65 \%$ of ATL cases might have been missed due to low response of the participating hospitals from endemic areas.

\section{Annual incidence of ATL in HTLV-1 endemic areas}

Results differ according to study methods and the HTLV-1 - positive rate of the study population. A series of cross-sectional survey for residents in Uwajima City (population size; 290, 464, HTLV1-positive rate; $5.4 \%$ in men and $8.3 \%$ in women) reported that the annual incidence of ATL was estimated to be approximately 6.1 in adults aged over 30 years per 100,000 populations (Kondo et al., 1985, 1987, 1989). In another cross-sectional studies by the use of the regional cancer registry data in Nagasaki prefecture (an endemic area, the population size; 1.56 million), the age-standardized annual incidence rate of ATL (among 100,000 individuals aged 30 or older) was estimated to be 10.5 for men and 6.0 for women during 1985-1995 (Arisawa et al., 2000) and 8.7 for men and 5.5 for women during 1995-2004 (Arisawa et al., 2009). There was no significant decrease in the overall incidence rate between the two decades, however, age-specific incidence of ATL among those aged over 60 years increased significantly during 1995-2004 compared to the period of 1985-1995 (Arisawa et al., 2009).

\section{Incidence of ATL among HTLV-1 carriers}

In studies used blood donors seropositive for HTLV-1, the annual incidence of ATL was estimated to be approximately 60 per 100,000 HTLV-1 carriers over 20 years old in Japan (Tajima, 1990) or approximately 116 for men and 66 for women per 100,000 HTLV1 carriers in Saga prefecture (an endemic area, the population size; 880,000; Tokudome et al., 1989). In a study used serological survey for residents in small cluster areas, The crude annual incidence of ATL was estimated to be 137.7 for men and 57.4 for women among 100,000 HTLV-1 carriers aged 30 years or older (Arisawa et al., 2000). Furthermore, in a study performed record linkage between the cancer registry and HTLV-1 carriers in hospital, the crude annual incidence of ATL was estimated to be 61 per 100,000 HTLV-1 carriers (Koga et al., 2010).

\section{Lifetime risk of ATL among HTLV-1 carriers}

For HTLV-1 carriers, the lifetime risk was estimated to be $4.5 \%$ for men and $2.6 \%$ for women in Saga prefecture (Tokudome et al., 1989), 6.6\% for men and $2.1 \%$ for women in Nagasaki prefecture (Arisawa et al., 2000), 6.9\% for men and 2.95\% for women in Uwajima City (Kondo et al., 1989), and 7.29\% for men and 3.78\% for women in a hospital-based study (Koga et al., 2010).

In summary, in Japan, nearly 1,000 new cases of ATL are diagnosed and nearly 1,000 patients die of ATL each year over a period of 20 years. The annual incidence of ATL among HTLV1 carriers is approximately 60 per 100,000 with the lifetime risk of $6-7 \%$ for men and $2-3 \%$ for women. The incidence was 1.35 times higher in men than in women, contrary to the higher HTLV-1-positive rate in women than in men. ATL occurs predominantly in elderly male carriers, and the mean age at diagnosis increased from the early 1950s in 1980 to the late 1960s recently. Most of Japanese epidemiological studies were population-based descriptive types using cancer registries, therefore those have limitations as follows; cases of smoldering ATL were excluded; hematological diagnoses were not performed. These limitations might have introduced an underestimation of the actual risk. 


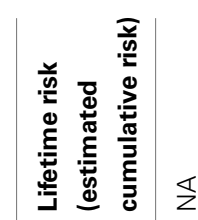

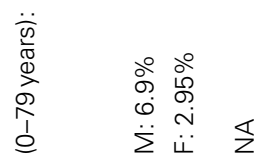

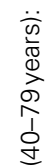

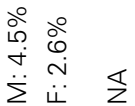

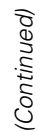

$\Sigma$

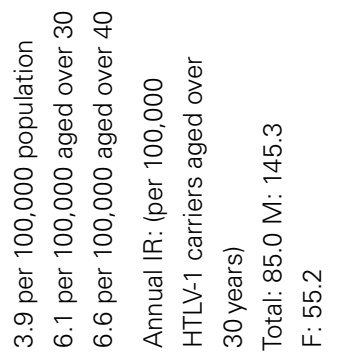

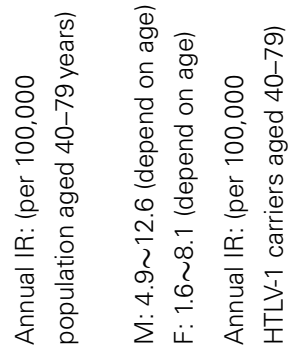

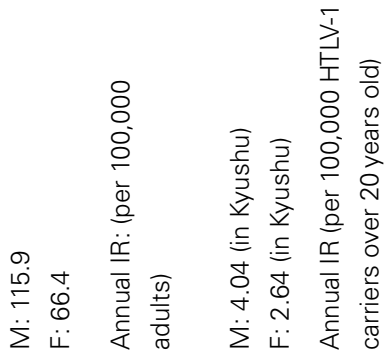

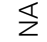

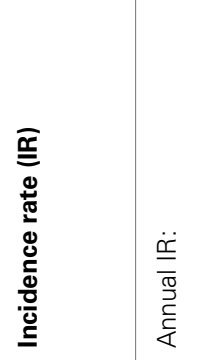

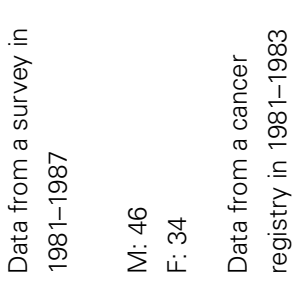

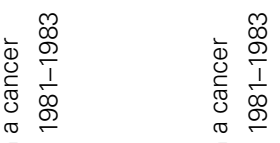

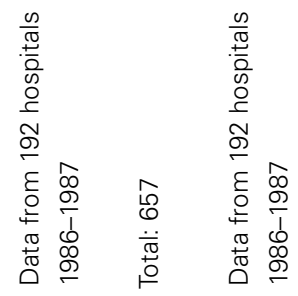

$\frac{8}{\stackrel{0}{\pi}}$

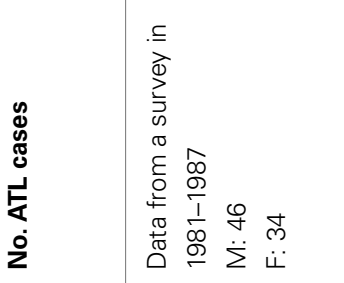

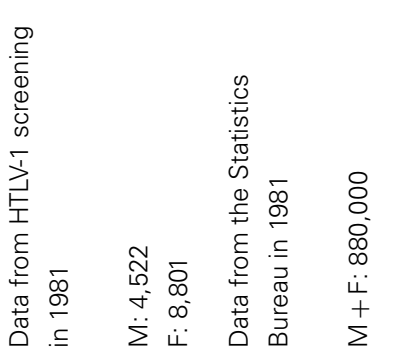

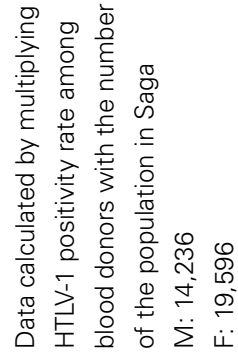

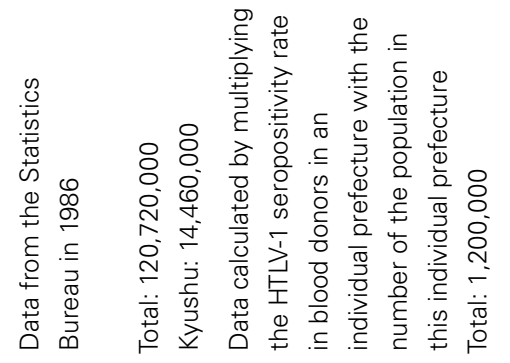
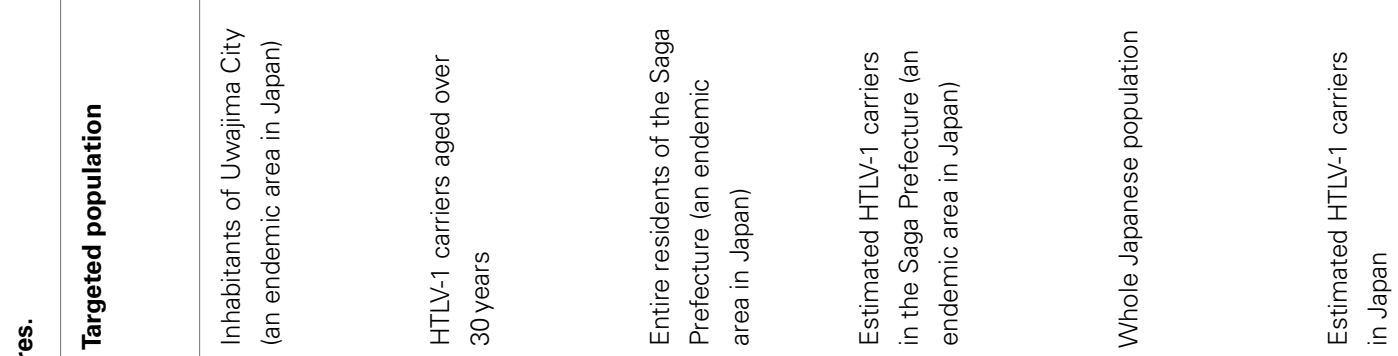

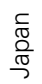

$\underset{\substack{\frac{0}{0} \\ \frac{0}{2}}}{\frac{1}{2}}$
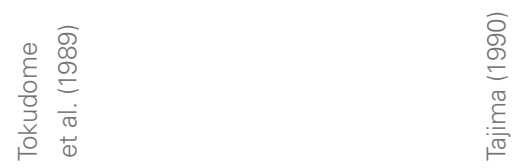

एँ

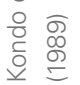

要
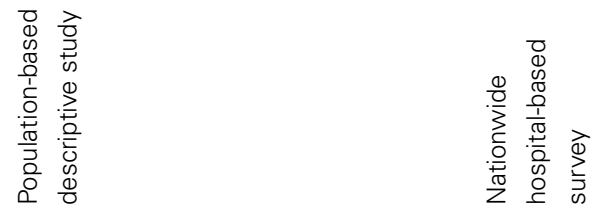


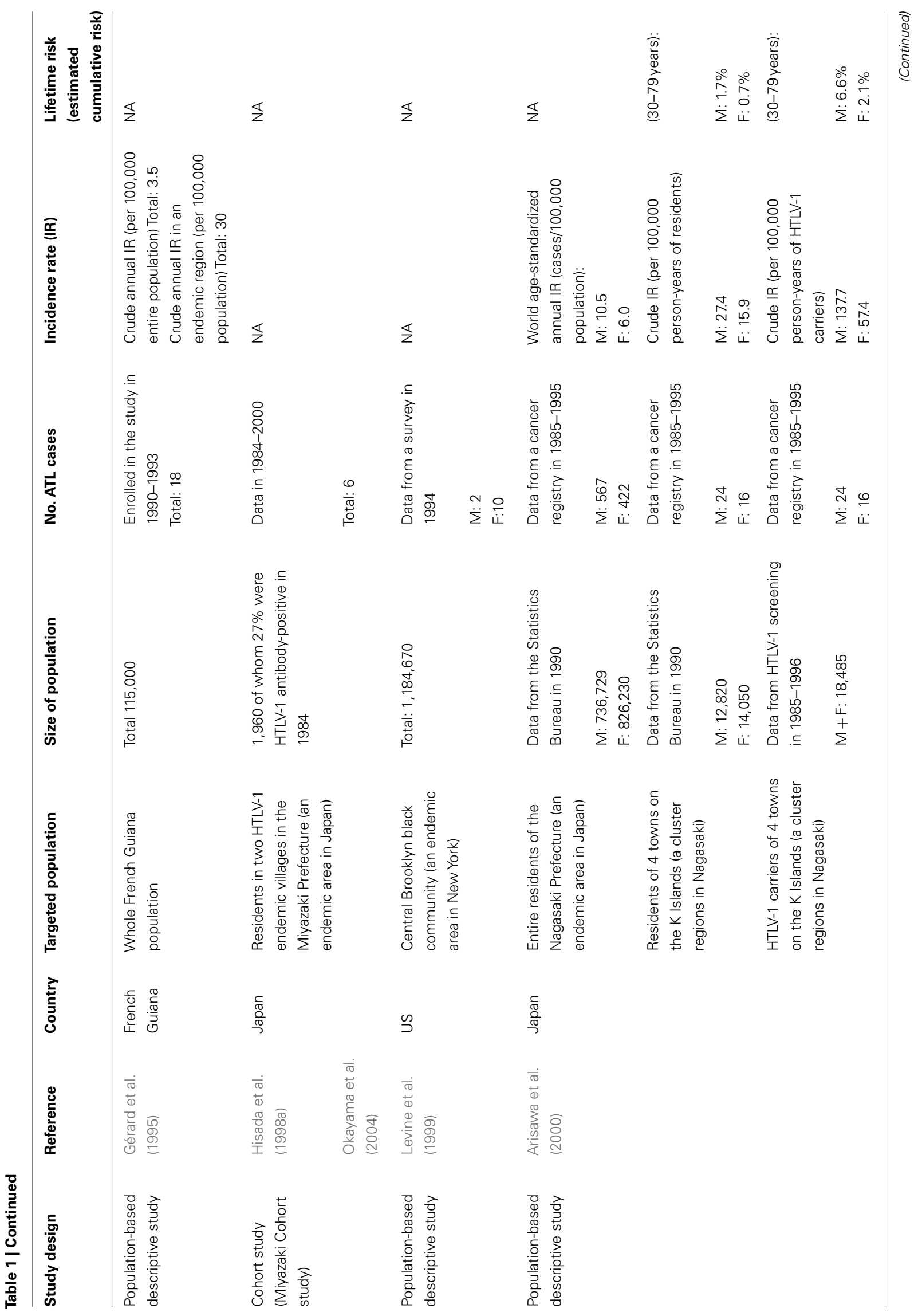




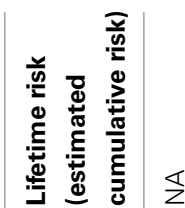

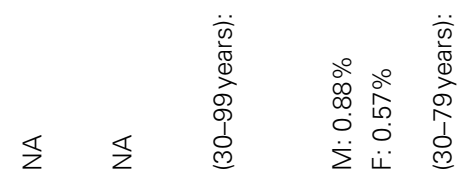

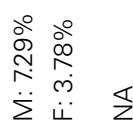

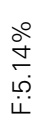

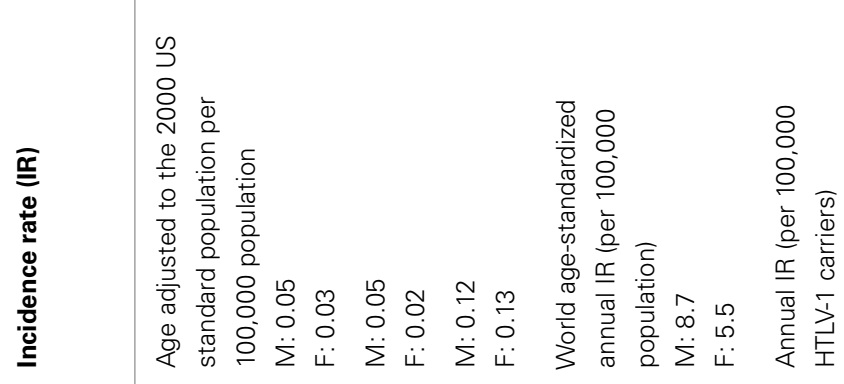

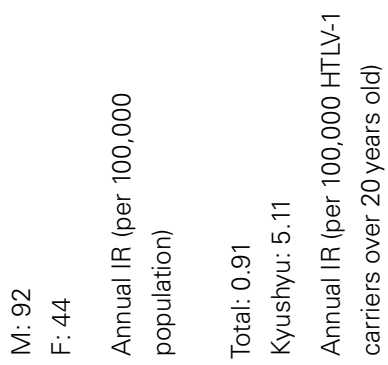

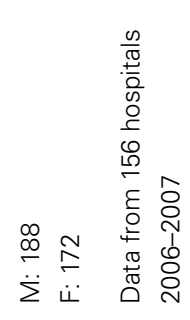

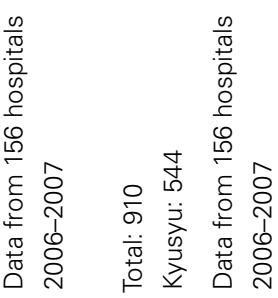

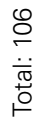
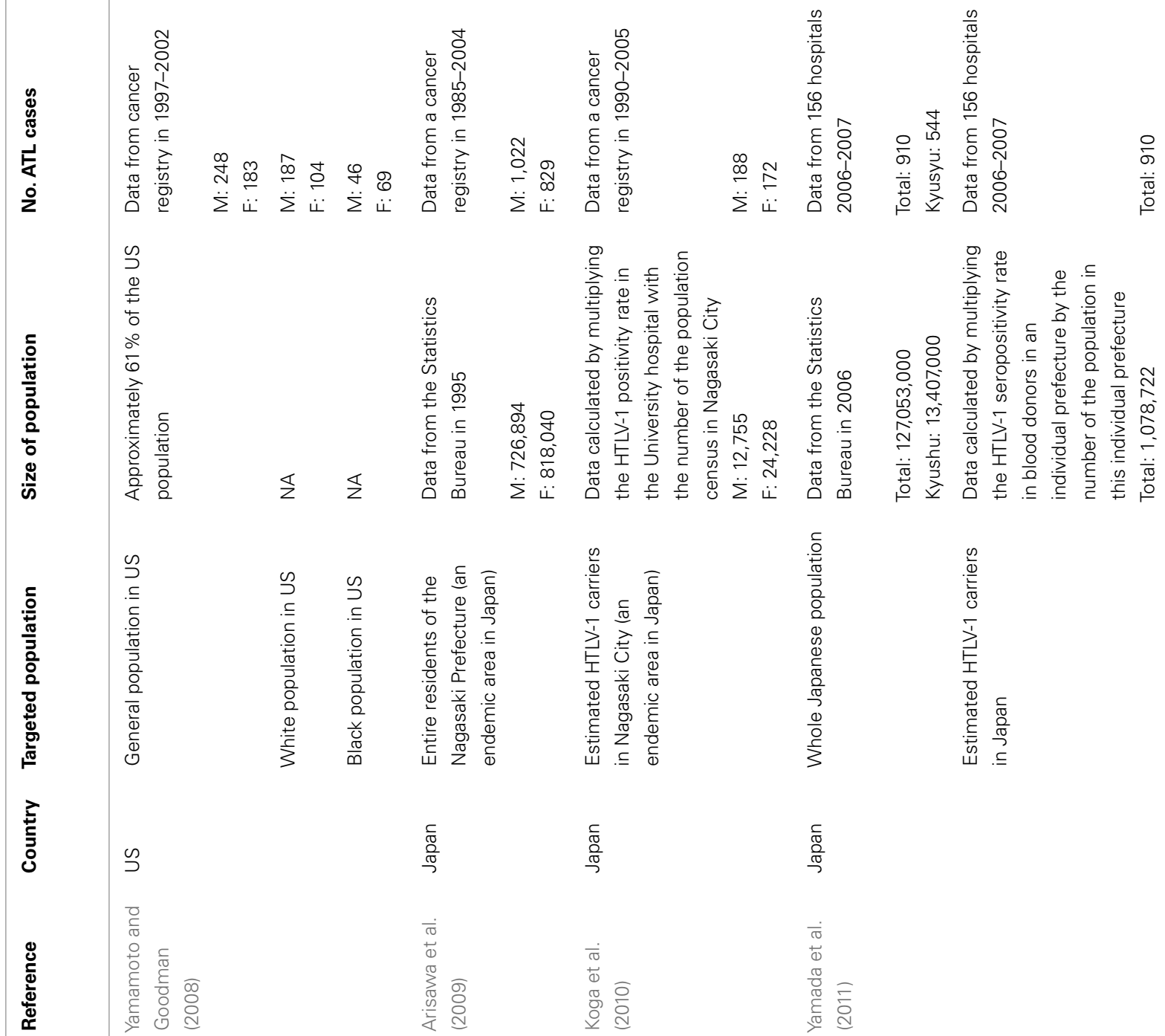

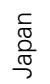

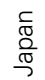
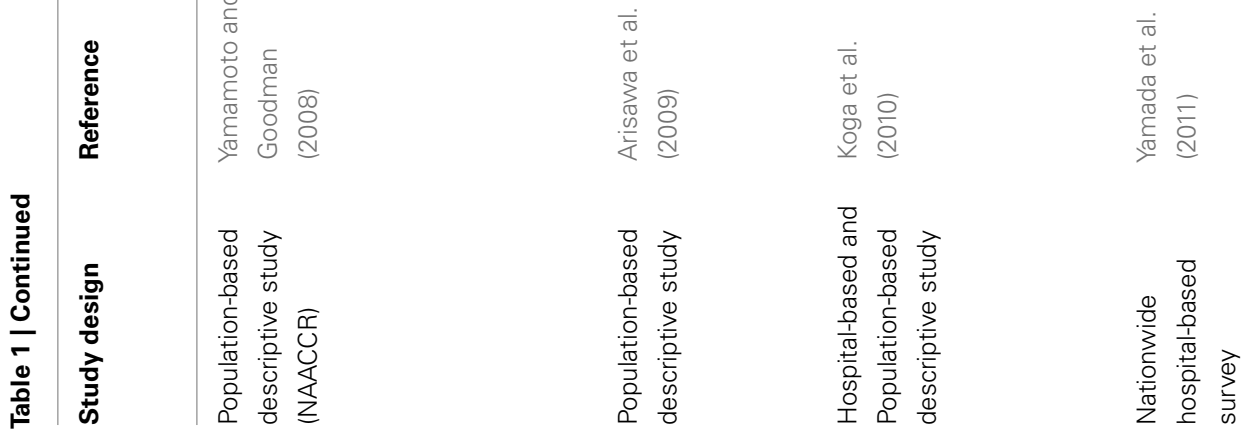


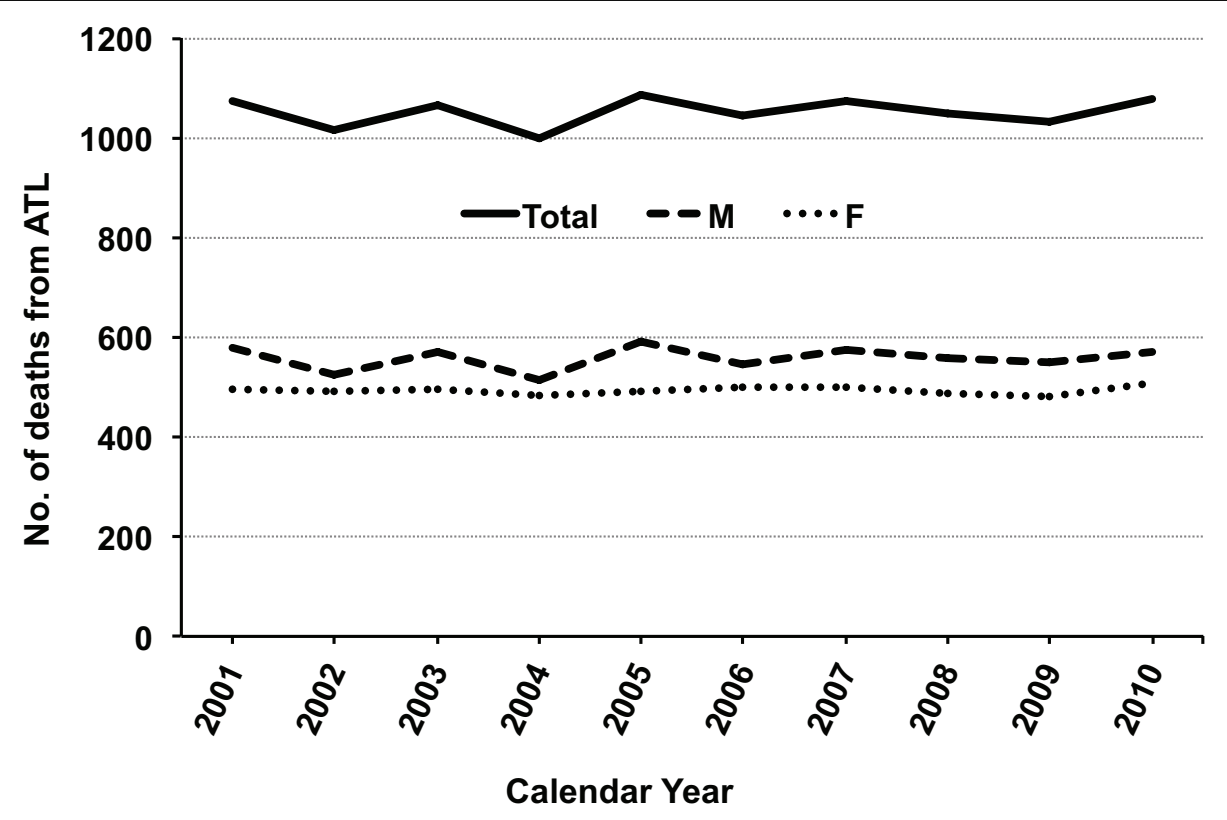

FIGURE 1 | Annual number of deaths from adult T-cell leukemia (ATL) during 2001-2010 in Japan. The raw data were obtained from vital statistics in the Portal Site of Official Statistics of Japan (e-Stat; accessed April 8, 2012). Abbreviations: M, male; F, female.

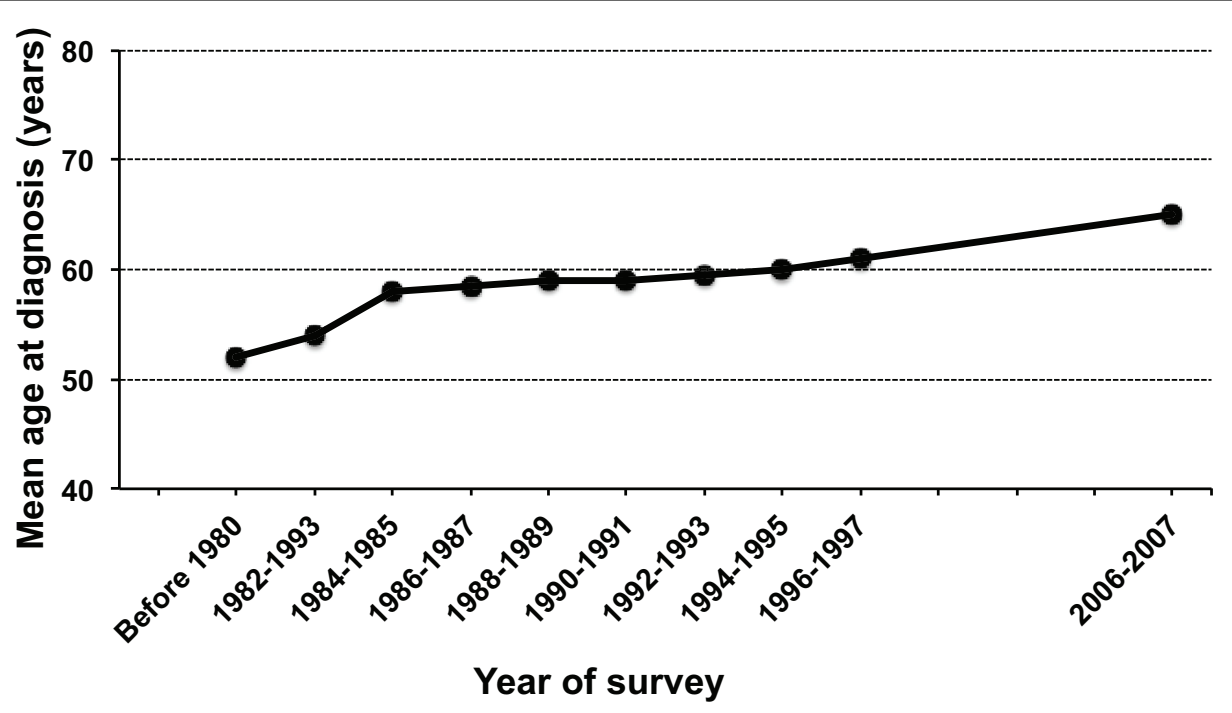

FIGURE 2 | Chronological changes in the mean age at diagnosis of adult T-cell leukemia (ATL) in Japan. The figure was modified from Figure 2 in Yamada et al. (2011).

\section{EAST ASIA (EXCLUDING JAPAN)}

Although there were several reports of blood donor screening for HTLV-1, no epidemiological study of ATL has been published from East Asian countries other than Japan because of the lower prevalence of HTLV-1 (less than $0.1 \%$ ). Nevertheless, several case series of ATL were available. The first case of ATL was reported in Taiwan in 1985 (Chen et al., 1985), in Korea in 1987 (Lee et al., 1987), and in China in 1995 (Zhuo et al., 1995). In Hong Kong, since the first case of ATL was reported in 1994 (Liang, 1994), all patients with T-cell lymphoma have been routinely screened for HTLV-1 antibody. In a registration study of lymphoma between 1993 and 2002 in Hong Kong, six cases of ATL were diagnosed among 5,911 lymphomas, in which ATL contributed to $0.1 \%$ of all cases of lymphoma and 1.3\% of T-cell lymphoma ( $\mathrm{Au}$ and Lo, 2005). Recently, 17 cases of ATL were reported from Taiwan (Lee et al., 2010), of those approximately $40 \%$ of the patients coinfected with HBV and HCV, which may be a characteristic of the Taiwanese ATL. 


\section{MIDDLE EAST}

The prevalence of HTLV-1 infection among healthy subjects is reported to be very low, less than $0.1 \%$, in Lebanon, Saudi Arabia, Egypt, and Kuwait (Proietti et al., 2005). However, there are some areas with a very high rate of HTLV-1 infection.

Northeast province of Iran (Mashhad, Sabzevar, and Neyshabour) and Urmia are known to be an endemic area for HTLV-1, where the prevalence of HTLV-1 infection was reported to be $0.34-0.77 \%$ in blood donors (Abbaszadegan et al., 2003; Khameneh et al., 2008), 1.7-12\% in cross-sectional studies (Meytes et al., 1990; Safai et al., 1996; Hedayati-Moghaddam et al., 2011; Azarpazhooh et al., 2012), and 2-3\% in community-based population (Rafatpanah et al., 2011).

Romania is also suggested to be an endemic area for HTLV1 because antibodies to HTLV-1 were found in $0.64 \%$ of blood donors (Paun et al., 1994), which was an extremely higher seroprevalence rate than in Europe and the USA. In Israel, HTLV-1 seropositive were discovered only in $0.0018 \%$ out of 276,000 blood donations, but a very high rate of infection (over 20\%) has been identified among a segregated community of Jews originated from the city of Mashhad in Iran (Miller et al., 1998).

Although, there are several clinical studies for ATL patients in the Middle East (Kchour et al., 2007, 2009), epidemiological studies regarding incidence and prevalence of ATL were not available in literature from the Middle East. There were several case reports of ATL, most of which were Mashhad origins or Romanian origins (Sidi et al., 1990; Veelken et al., 1996; Shtalrid et al., 2005; Bitar et al., 2009).

\section{UNITED STATES}

HTLV-1 and ATL are extremely rare in North America. Several ATL cases have been reported sporadically (Catovsky et al., 1982). Most of the cases were migrants from endemic areas. A populationbased survey reported that the annual incidence in African Americans in central Brooklyn (population size; 1,184,670) was estimated to be approximately 3.2 per 100,000 person-years (Levine et al., 1999). An interesting finding in their study was that the male-to-female ratio of 1:3 was different from the male dominance reported in Japan. Recent cancer registry systems for hematological malignancies allow a precise evaluation of epidemiological features of ATL in the USA. In a recent report from the North American Association of Central Cancer Registries (NAACCR; Yamamoto and Goodman, 2008), a total of 431 cases (248 men and 183 women) of ATL (ICD-O-3 code; 9,827) were registered between 1997-2002, showing that the age adjusted incidence rate was 0.05 for men and 0.03 for women per 100,000 population. The study also reported a racial difference in the incidence rate, showing that African Americans had the highest rates of ATL (0.12 for men and 0.13 for women per 100,000 population). A possible explanation for this observation might be the higher number of migrants from endemic areas of the Caribbean and parts of Sub-Saharan Africa rather than a racial difference in susceptibility.

\section{THE CARIBBEAN}

In the early 1980s, eight patients were diagnosed with ATL in the USA, and all of them were Blacks from the Caribbean (Blattner et al., 1982). Since then, Central/South America and the Caribbean are known as areas of high prevalence of HTLV-1. Although there is no concrete epidemiological report regarding the incidence or prevalence of ATL from Central and South America, several case series have been published. A regional registration study of Jamaica reported a total of 126 cases of ATL (acute $46.8 \%$, lymphoma $27 \%$, chronic 20.6\%, and smoldering 5.6\%) between January 1985 and July 1995 (Hanchard, 1996). The mean age was 43 years old (1785 years old), which is similar to that reported in Brazil (43 years; Pombo de Oliveira et al., 1995) but younger than that in Japan (5060 years; Yamaguchi et al., 1987). There is definite evidence that the age at diagnosis in Central/South America and the Caribbean is younger than that in Japan. This difference in the age at diagnosis might be due to different environmental backgrounds.

\section{CENTRAL AND SOUTH AMERICA}

In Central and South America, HTLV-I has been shown to be endemic mainly in populations of African ancestry and in some populations of Japanese origin.

Brazil has the highest HTLV-1 seroprevalence rate in healthy subjects (approximately 1\%), especially in Rio de Janeiro and Salvador $(1.8 \%)$ on the northeast coast of the country where the population is largely of African descent. ATL accounts for approximately $30 \%$ of patients with T-cell malignancies in Brazil (Pombo de Oliveira et al., 1995; Farias de Carvalho et al., 1997). A Brazilian ATLL Study Group identified 195 cases of ATL in the national registry of T-cell malignancies between 1994 and 1998 (Pombo de Oliveira et al., 1999), but no epidemiological indicators were available. In Argentina, HTLV-1 infection is known to be highly prevalent among Native Americans living in the Andes, and ATL accounts for approximately $14.7 \%$ of patients with lymphoid malignancies (Marin et al., 2002).

Chile is a non-tropical country but small case series of ATL patients have been reported frequently (Cabrera et al., 1994, 1999, 2003). The characteristics of Chilean ATL were reported that the most of patients were of Caucasian origin, and age at diagnosis ( 50 years old) was younger than Japanese patients but older than those from other Latin American countries. According to the recent pathological study in Chile, ATL accounts for $0.5 \%$ of patients with of NHL (Cabrera et al., 2012).

French Guiana (population 115,000), an overseas French administrative district located on the northeast coast of the South American continent between Brazil and Surinam, is also known to be an area of high endemicity for HTLV-I (Plancoulaine et al., 1998; Talarmin et al., 1999, Pouliquen et al., 2004). Although the population consists of various ethnic groups, a high seroprevalence of HTLV-I (8\%) and a high incidence of cases of ATL were found among the Noirs-Marrons, an isolated population descended from Surinam slaves (Gérard et al., 1995; Tuppin et al., 1995; Plancoulaine et al., 1998). An epidemiological study was performed in French Guiana to determine the prevalence and incidence of ATL (Gérard et al., 1995). Only 18 patients with ATL (8 acute forms, 8 lymphoma types, and 2 smoldering cases) were enrolled during 1990-1993 and the annual crude incidence rate was estimated to be around 3.5 per 100,000 populations. However, in a small remote ethnic group of African origin (around 6200 inhabitants), the annual crude incidence rate was the highest to be around 30 per 100,000 populations. 
Table 2 | Risk factors for the development of ATL with regard to the HTLV-1 carrier status.

\begin{tabular}{ll}
\hline & Reference \\
\hline Host susceptibility & \\
Vertical infection with HTLV-1 as infant & Murphy et al. (1989) \\
Attained at an age of >50 years & Many references \\
Male sex & Many references \\
HLA-A*26, HLA-B*4002, HLA-B*4006, and & Yashiki et al. (2001) \\
HLA-B*4801 (Japanese ATL) & \\
Co-infected with Strongyloides stercoralis & \\
Laboratory markers & \\
A high level of sil-2R, more than 500 U/ml & Arisaw et al. (2002) \\
A high level of anti-HTLV-1, titer more & Arisaw et al. (2002) \\
than $\times 1,024$ & Hisada et al. (1998a) \\
A high level of circulating abnormal & \\
lymphocytes, more than 0.6\% & Hisada et al. (1998b) \\
A low level of of anti-Tax reactivity & Imaizumi et al. (2005) \\
A high level of white blood cell count, more than \\
$9,000 / \mu L$
\end{tabular}

ATL, adult T-cell leukemia; HTLV-1, human T-cell leukemia virus type 1; HLA, human leukocyte antigen; PBMC, peripheral blood mononuclear cell; slL-2R, soluble interleukin-2 receptor.

\section{AFRICA AND EUROPE}

In Africa, a high HTLV-I seroprevalence rate $(>2 \%$ in the adult population) has been reported in sub-Saharan African countries, especially in Gabon (Hunsmann et al., 1984; Delaporte et al., 1988; Gessain, 1996; Etenna et al., 2008; Gonçalves et al., 2010). Although there are many reports regarding the HTLV-I seroprevalence rates in African countries, only a few epidemiological studies of ATL were available. In a case-control study including NHL and control that performed in Gabon, only four cases of the 26 patients with NHL fitted the criteria of ATL (Delaporte et al., 1993), but further information on epidemiological feature of ATL was not available.

In Europe, HTLV-1 is endemic in Southern Italy (Manzari et al., 1985). Several case series of ATL were reported from Europe (Manzari et al., 1985; Gessain et al., 1990). Most of ATL patients were African origin from high-HTLV-1-endemic areas (West Indies, Nigeria, and other African areas); however, some patients had no background regarding endemic areas (Manzari et al., 1985).

\section{RISK FACTORS FOR ATL IN HTLV-1 CARRIERS}

Although a variety of genetic abnormalities due to HTLV-1 infection have been reported to explain the characteristics of ATL oncogenesis, HTLV-1 infection alone is not sufficient to develop ATL from HTLV-1 carrier status. Risk factors for developing ATL in HTLV-1 carriers have been investigated in many epidemiological and clinical studies (Table 2).

\section{HOST SUSCEPTIBILITY}

Age is a well-known risk factor for the development of ATL. ATL occurs mostly in adults, at least 20-30 years after HTLV-1 infection.
However, the age at onset differs across geographic areas, which may be affected by racial or environmental characteristics. In Japan in the early 1980s, an average age at diagnosis of ATL was reported to be individuals in their early 1950s (The T- and B-Cell Malignancy Study Group, 1981, 1985), but the age at diagnosis increased yearly, reaching 65 years in the latest nationwide survey for ATL (Yamada et al., 2011). However, the average age at diagnosis of ATL in Jamaican and Brazilian series was reported to be individuals in the 1940s (43 years in Jamaica and 44 years in Brazil; Hanchard, 1996; Pombo de Oliveira et al., 1999), which is younger than that in Japan (Yamaguchi et al., 1987).

The age at the time of HTLV-1 infection is also a very important risk factor for the development of ATL. Individuals infected in childhood (vertical transmission) may be at higher risk for developing ATL (Murphy et al., 1989). ATL seldom develops in individuals infected in adulthood, although no epidemiological study has proven this fact. There was one case report describing that a female HTLV-1 carrier known as conclusively transmitted horizontally by her partner developed ATL (Sakuma et al., 1988). To clarify whether or not ATL develops among individuals infected in adulthood, a large prospective follow-up study is required.

Male sex is considered a risk factor for ATL. In most studies from Japan, the incidence of ATL is two- and threefold higher in male carriers than in female carriers, which is contrary to the higher rate of HTLV-1 positivity in women than in men. However, a population-based survey in central Brooklyn reported that the annual incidence of ATL was higher in women than in men (maleto-female ratio of 1:3; Levine et al., 1999). Modeling data from Jamaican series also showed a higher cumulative lifetime risk of ATL in women than in men $(4.0 \%$ for men and $4.2 \%$ for women; Murphy et al., 1989). The reason for the sex-related differences in the incidence rate of ATL between Japan and other regions is unknown.

It seems unlikely that there are apparent ethnical differences in susceptibility to infection by HTLV-1 and developing ATL. A higher incidence of ATL was found individual of African origin than in others (Manzari et al., 1985; Gessain et al., 1990; Yamamoto and Goodman, 2008), however, most of patients of African origin came from HTLV-1 endemic areas.

Earlier epidemiologic studies have found that ATL patients are more likely to have a family history of lymphoid malignancy (Ichimaru et al., 1979; The T- and B-Cell Malignancy Study Group, 1981). Since then, several host genetic background factors influencing the onset of ATL have been investigated. Human leukocyte antigen (HLA) is a candidate for the genetic factors controlling the immune response against the viral antigen. Specific HLA antigen alleles have been reported to be associated with an increased risk of developing ATL (Uno et al., 1988). The allele frequencies of HLA-A*26, HLA-B*4002, HLA-B*4006, and HLA-B*4801 were significantly higher in ATL patients than in asymptomatic HTLV-1 carriers in southern Japan, and ATL patients possessing these alleles developed ATL 12.6 years earlier than patients with other alleles (Yashiki et al., 2001). Ethnic differences in HLA alleles related to ATL were also investigated in another study (Sonoda et al., 2011).

HTLV-1 carriers with abnormal immune system may be at high-risk of developing ATL. Several studies reported that HTLV1 carriers co-infected with Strongyloides stercoralis are considered 
a high-risk group for developing ATL because of the clonal proliferation of HTLV-1-infected lymphocytes and high proviral load (Nakada et al., 1987; Yamaguchi et al., 1988; Plumelle et al., 1997; Gabet et al., 2000). Satoh et al. (2002) suggested that S. stercoralis infection induces polyclonal expansion of HTLV-1-infected cells by activating the interleukin 2/interleukin 2 receptor (IL-2/IL2R) system in dually infected carriers, which may be a precipitating factor for ATL. The immunosuppressive state has been reported to potentially contribute to ATL development in HTLV-1 carriers. There were several case reports of ATL developed in HTLV-1 carriers undergoing immunosuppressive treatment after living-donor liver transplantation (Kawano et al., 2006; Yoshizumi et al., 2012) and kidney transplantation (Hoshida et al., 2001).

\section{LABORATORY MARKERS}

Several laboratory abnormalities were found to be markers for the development of ATL. Kamihira et al. (1994) measured prospectively soluble IL-2R (sIL-2R) levels and lactate dehydrogenase (LDH) levels in HTLV-1 carriers, reporting that the increasing level of sIL-2R may be a more sensitive indicator of ATL than LDH. A nested case-control study also showed that high levels of sIL-2R (more than $500 \mathrm{U} / \mathrm{mL}$ ) and HTLV-1 antibody titers (more than 1,024) were independently associated with an increased risk of developing ATL (Arisaw et al., 2002). Imaizumi et al. (2005) analyzed the outcomes of $50 \mathrm{HTLV}-1$ carriers with monoclonal proliferation of HTLV-1-infected T cells in a 20-year follow-up study, reporting that a high white blood cell count more than $9,000 / \mu \mathrm{L}$ was a potential prognostic factor for developing ATL, even after adjustment for age, sex, and relative lymphocyte counts.

A series of the Miyazaki Cohort Study (population size; 1,960 people, of whom $27 \%$ were HTLV-1 antibody-positive) reported that an HTLV-1 carrier with a high anti-HTLV-1 titer (odds ratio; 1.6), a high number of circulating abnormal lymphocytes, and a low anti-Tax reactivity were associated with a greater risk of developing ATL (Mueller et al., 1996; Hisada et al., 1998a,b). Recently, an international ATL Cohort Consortium study by merging eight cohorts from Japan, Jamaica, the United States, and Brazil examined serologic markers of HTLV-I pathogenesis and host immunity in 53 ATL cases and 150 matched asymptomatic HTLV-I carriers (Birmann et al., 2011). The study confirmed that above-median sIL-2R and anti-Tax seropositivity were independently associated with an increased ATL risk, and found that above-median total immunoglobulin E levels predicted a lower ATL risk.

Aberrant expression of cell-surface antigens is usually used for clinical routine diagnosis on ATL. ATL cells phenotypically express CD4, CCR4, and CD25. However, data of cell-surface antigens rarely used for a prognostic marker of ATL from HTLV-I carriers. Two studies reported that expression of CD3, CD7, and CD26 on HTLV-1-infected cells were diminished in acute and chronic ATL and those were slightly down-regulated in smoldering ATL (Tsuji et al., 2004; Tian et al., 2011). These results suggest that the down-regulation of those cell-surface antigens could be possible predict markers for the early phase leukemogenesis of ATL from HTLV-1 carriers. A resent study serially evaluated cell-surface antigens on HTLV-1-infected cells in HTLV-1 carriers, smoldering ATL, and chronic ATL, by taking into consideration the pattern of Southern blot hybridization and proviral load (Kamihira et al.,
2012). The report suggests that the decreasing expression of CD26 and the decreasing ratio of CD26/CD25 are novel biomarkers for prediction of clonal bands and discrimination of carriers and smoldering ATL.

\section{PROVIRUS-INTEGRATION STATUS}

Among HTLV-1 carriers, there exist a group of cases having the monoclonal integration of HTLV-1 proviral DNA in mononuclear cells without signs of malignant proliferation or clinical signs and symptoms related to leukemia (Ikeda et al., 1993). Such carriers have been suggested to be a high-risk group of developing ATL, but their prognosis varied from being stable carriers for long to developing ATL (Ikeda et al., 1993; Imaizumi et al., 2005). There are only a few epidemiological studies to investigate the significance of the provirus-integration status on non-malignant infected cells from asymptomatic HTLV-1 carriers.

Nakada et al. (1987) reported that patients with S. stercoralis infection and co-infected with HTLV-1 had a high frequency (35\%) of patients presenting a monoclonal integration of HTLV-1 proviral DNA in their blood lymphocytes. Carvalho and Da Fonseca Porto (2004) also The author also found a correlation between monoclonal integration of proviral DNA and abnormal lymphocytes in peripheral blood, with a trend for greater severity of the parasitic infection. Although several studies reported that HTLV-1 carriers co-infected with $S$. stercoralis are considered a high-risk group for developing ATL (Nakada et al., 1987; Yamaguchi et al., 1988; Plumelle et al., 1997; Gabet et al., 2000), no study investigated the clinical significance of the monoclonal integration of HTLV-1 proviral DNA in their blood lymphocytes in HTLV-1 carriers with S. stercoralis.

\section{PROVIRAL LOAD}

In the area of viral oncogenesis, there are accumulated data indicating a relationship between an increased viral load and viral-associated malignancies. HTLV-1 proviral DNA load in the peripheral blood mononuclear cells (PBMCs) are also evaluated in some epidemiological and clinical studies to support the hypothesis that increased HTLV-1 proviral load level is an important predictor of developing ATL.

A cross-sectional study (Manns et al., 1999) and a series of the Miyazaki cohort study (Tachibana et al., 1992; Hisada et al., 1998a,b; Okayama et al., 2004) reported that HTLV-1 proviral load level was higher in HTLV-1 carriers who developed ATL than in asymptomatic HTLV-1 carriers. However, the proviral load was measured only in a small number of subjects in the above literature.

Several large-scale prospective studies support results from the previous small studies that an increased HTLV-1 proviral load is an important predictor of developing ATL. In Japan in 2002, a nationwide prospective cohort study for asymptomatic HTLV-1 carriers, the Joint Study on Predisposing Factors of ATL Development (JSPFAD), was initiated (Yamaguchi et al., 2007) to investigate viral- and host-specific determinants of the development of ATL in more detail. In the cohort of 1,218 asymptomatic HTLV-1 carriers (426 men and 792 women), 14 subjects progressed to overt ATL during a follow-up of 1981.2 person-years (Iwanaga et al., 2010). All of the 14 subjects were among those with the highest group of baseline proviral load (range, 4.17-28.58 copies/100 
PBMCs). Multivariate Cox analyses indicated that a higher proviral load (more than 4 copies/100 PBMCs) is an independent risk factor for progression of ATL, even after adjusting for sex, age, family history of ATL, and other possible risk factors. The result indicated that HTLV-1 carriers with higher HTLV-1 proviral load levels belong to the high-risk group of carriers who develop ATL and in whom any measures to prevent the development of ATL should be instituted.

Nevertheless, the association between HTLV-1 proviral load and disease development remains unclear because a higher proviral load is also an important predictor in patients with HTLV-1associated myelopathy/tropical spastic paraparesis (HAM/TSP). Further viral markers are needed to determine the function of a higher HTLV-1 proviral load to direct the way to developing ATL or developing HAM/TSP from HTLV-1 carriers.

\section{CONCLUDING REMARKS}

Although many prior studies found important epidemiological evidence on ATL and risk factors for the development of ATL in HTLV-1 carriers, limited data are available on the valid annual incidence of ATL from longitudinal prospective studies. Existing predisposing factors are still insufficient to explain the characteristics of ATL oncogenesis. Unknown risk factors may be involved in the acquisition of malignant characteristics of HTLV-1 infected

\section{REFERENCES}

Abbaszadegan, M. R., Gholamin, M., Tabatabaee, A., Farid, R., Houshmand, M., and Abbaszadegan, M. (2003). Prevalence of human T-lymphotropic virus type 1 among blood donors from Mashhad, Iran. J. Clin. Microbiol. 41, 2593-2595.

Arisaw, K., Katamine, S., Kamihira, S., Kurokawa, K., Sawada, T., Soda, M., Doi, H., Saito, H., and Shirahama, S. (2002). A nested case-control study of risk factors for adult T-cell leukemia/lymphoma among human T-cell lymphotropic virus type-I carriers in Japan. Cancer Causes Control 13, 657-663.

Arisawa, K., Soda, M., Endo, S., Kurokawa, K., Katamine, S., Shimokawa, I., Koba, T., Takahashi, T., Saito, H., Doi, H., and Shirahama, S. (2000). Evaluation of adult T-cell leukemia/lymphoma incidence and its impact on non-Hodgkin lymphoma incidence in southwestern Japan. Int. J. Cancer 85, 319-324.

Arisawa, K., Soda, M., Ono, M., Uemura, H., Hiyoshi, M., and Suyama, A. (2009). Trends of incidence rate of adult T-cell leukemia/lymphoma in an HTLV-1 endemic area in Japan. Int. J. Cancer 125, 737-738.

$\mathrm{Au}$, W. Y., and Lo, J. Y. (2005). HTLV-1-related lymphoma in Hong Kong Chinese. Am. J. Hematol. 78, 80-81.
Azarpazhooh, M. R., Hasanpour, K., Ghanbari, M., Rezaee, S. A., Mashkani, B., HedayatiMoghaddam, M. R., Valizadeh, N., Farid Hosseini, R., Foroghipoor, M., Soltanifar, A., Sahebari, M., Azadmanesh, K., Hassanshahi, G., and Rafatpanah, H. (2012). Human T-lymphotropic virus type 1 prevalence in Northeastern Iran, Sabzevar: an epidemiologic-based study and phylogenetic analysis. AIDS Res. Hum. Retroviruses 28, 895-901.

Birmann, B. M., Okayama, A., Kim, N., Arisawa, K., Breen, E. C., Carneiro-Proietti, A. B. F., Falk, K. I., Hanchard, B., Inoue, M., Martínez-Maza, O., Murphy, E. L., Pfeiffer, R. M., Sawada, T., Stuver, S. O., Tsugane, S., Li, H., Suppan, C. A., Mueller, N. E., and Hisada, M. (2011). Altered host immunity, human $\mathrm{T}$ lymphotropic virus type I replication, and risk of adult T-cell leukemia/lymphoma: a prospective analysis from the ATL Cohort Consortium. Retrovirology 8, A81.

Bitar, N., Hajj, H. E., Houmani, Z., Sabbah, A., Otrock, Z. K., Mahfouz, R., Zaatari, G., and Bazarbachi, A. (2009). Adult Tcell leukemia/lymphoma in the Middle East: first report of two cases from Lebanon. Transfusion 49, 1859-1864.

cells. Further well-designed epidemiological studies are needed to fully understand the oncogenesis of ATL.

Even though the incidence of ATL is relatively low among HTLV-1 carriers and a novel promising agent, mogamulizumab (humanized anti-CCR4 monoclonal antibody), is released (Ishida et al., 2003, 2012), preventing new HTLV-1 infections and the development of ATL are major public health concerns in HTLV-1 endemic countries in the world. In Japan, there are approximately one million of HTLV-1 carriers, 1,000 new ATL cases, and 1,000 new deaths from ATL every year. However, only recently has the Japanese government for the first time begun to implement a nationwide comprehensive package of measures covering the prevention of mother-to-child HTLV-1 transmission and the development of medical researches on HTLV-1 and ATL (http://www.kantei.go.jp/foreign/kan/actions/201009/13htlv_e. $\mathrm{html}$ ). The challenge in the next few years will be to reduce the number of HTLV-1 carriers, to develop an easy method that allows identification of high-risk carriers, and to implement earlier therapeutic interventions for carriers with high-risk markers.

\section{ACKNOWLEDGMENTS}

A part of this review was supported by grants (201123050A, H23-gan rinsho-ippan-021, H23-gan rinsho-ippan-022) from the Ministry of Health, Labor, and Welfare in Japan.

Blattner, W. A., Kalyanaraman, V. S., Robert-Guroff, M., Lister, T. A., Galton, D. A., Sarin, P. S., Crawford, M. H., Catovsky, D., Greaves, M., and Gallo, R. C. (1982). The human type-C retrovirus, HTLV, in Blacks from the Caribbean region, and relationship to adult $\mathrm{T}$-cell leukemia/lymphoma. Int. J. Cancer 30, 257-264.

Cabrera, M. E., Labra, S., Catovsky, D., Ford, A. M., Colman, S. M., Greaves, M. F., and Matutes, E. (1994). HTLV-I positive adult T-cell leukaemia/lymphoma (ATLL) in Chile. Leukemia 8, 1763-1767.

Cabrera, M. E., Labra, S., Meneses, P., Matutes, E., Cartier, L., Ford, A. M., and Greaves, M. F. (1999). Adult T cell leukemia lymphoma in Chile. A clinical pathologic and molecular study of 26 patients. Rev. Med. Chil. 127, 935-944.

Cabrera, M. E., Marinov, N., Guerra, C., Morilla, R., and Matutes, E. (2003). Chronic lymphoproliferative syndromes in Chile. A prospective study in 132 patients. Rev. Med. Chil. 131, 291-298.

Cabrera, M. E., Martinez, V., Nathwani, B. N., Muller-Hermelink, H. K., Diebold, J., MacLennan, K. A., Armitage, J., and Weisenburger, D. D. (2012). Non-Hodgkin lymphoma in Chile: a review of 207 consecutive adult cases by a panel of five expert hematopathologists. Leuk. Lymphoma 53, 1311-1317.

Carvalho, E. M., and Da Fonseca Porto, A. (2004). Epidemiological and clinical interaction between HTLV-1 and Strongyloides stercoralis. Parasite Immunol. 26, 487-497.

Catovsky, D., Greaves, M. F., Rose, M., Galton, D. A., Goolden, A. W., McCluskey, D. R., White, J. M., Lampert, I., Bourikas, G., Ireland, R., Brownell, A. I., Bridges, J. M., Blattner, W. A., and Gallo, R. C. (1982). Adult T-cell lymphoma-leukaemia in Blacks from the West Indies. Lancet 1, 639-643.

Chen, P. M., Chiu, C. F., Chiou, T. J., Tzeng, C. H., and Chiang, B. N. (1985). Adult T-cell leukemia. First case reported in Taiwan. Nippon Ketsueki Gakkai Zasshi 8, 1035-1041.

Delaporte, E., Dupont, A., Peeters, M., Josse, R., Merlin, M., Schrijvers, D., Hamono, B., Bedjabaga, L., Cheringou, H., Boyer, F., BrunVézinet, F., and Larouzé, B. (1988). Epidemiology of HTLV-I in Gabon (Western Equatorial Africa). Int. J. Cancer 42, 687-689.

Delaporte, E., Klotz, F., Peeters, M., Martin-Prevel, Y., Bedjabaga, L., Larouzé, B., Nguembi-Mbina, C., Walter, P., and Piot, P. (1993). NonHodgkin lymphoma in Gabon and its relation to HTLV-I. Int. J. Cancer $53,48-50$. 
Etenna, S. L., Caron, M., Besson, G., Makuwa, M., Gessain, A., Mahé, A., and Kazanji, M. (2008). New insights into prevalence, genetic diversity, and proviral load of human T-cell leukemia virus types 1 and 2 in pregnant women in Gabon in equatorial central Africa. J. Clin. Microbiol. 46, 3607-3614.

Farias de Carvalho, S. M., Pombo de Oliveira, M. S., Thuler, L. C., Rios, M., Coelho, R. C., Rubim, L. C., Silva, E. M., Reis, A. M., and Catovsky, D. (1997). HTLV-I and HTLV-II infections in hematologic disorder patients, cancer patients, and healthy individuals from Rio de Janeiro, Brazil. J. Acquir. Immune Defic. Syndr. Hum. Retrovirol. 15, 238-242.

Gabet, A. S., Mortreux, F., Talarmin, A., Plumelle, Y., Leclercq, I., Leroy, A., Gessain, A., Clity, E., Joubert, M., and Wattel, E. (2000). High circulating proviral load with oligoclonal expansion of HTLV-1 bearing T cells in HTLV-1 carriers with strongyloidiasis. Oncogene 19, 4954-4960.

Gérard, Y., Lepere, J. F., Pradinaud, R., Joly, F., Lepelletier, L., Joubert, M., Sainte Marie, D., Mahieu, R., Vidal, A. U., Larregain-Fournier, D., Valensi, F., Moynet, D., de Thé, G., Guillemain, B., Moreau, J. P., and Gessain, A. (1995). Clustering and clinical diversity of adult $\mathrm{T}$ cell leukemia/lymphoma associated with HTLV-I in a remote black population of French Guiana. Int. J. Cancer 60, 773-776.

Gessain, A. (1996). "Epidemiology of HTLV-I and associated diseases," in Human T-Cell Lymphotropic Virus Type 1, eds P. Höllsberg and D. A. Hafler (Chichester: John Wiley \& Sons Ltd.), 33-64.

Gessain, A., Gout, O., Saal, F., Daniel, M. T., Rio, B., Flandrin, G., Sigaux, F., Lyon-Caen, O., Periès, J., and de-Thé, G. (1990). Epidemiology and immunovirology of human Tcell leukemia/lymphoma virus type I-associated adult T-cell leukemia and chronic myelopathies as seen in France. Cancer Res. 50, 5692S5696 S.

Gonçalves, D. U., Proietti, F. A., Ribas, J. G., Araújo, M. G., Pinheiro, S. R., Guedes, A. C., and Carneiro-Proietti, A. B. (2010). Epidemiology, treatment, and prevention of human Tcell leukemia virus type 1-associated diseases. Clin. Microbiol. Rev. 23, 577-589.

Hanchard, B. (1996). Adult T-cell leukemia/lymphoma in Jamaica: 1986-1995. J. Acquir. Immune Defic. Syndr. Hum. Retrovirol. 13, S20-S25.
Hattori, T., Uchiyama, T., Toibana, T., Takatsuki, K., and Uchino, H. (1981). Surface phenotype of Japanese adult T-cell leukemia cells characterized by monoclonal antibodies. Blood 58, 645-647.

Hedayati-Moghaddam, M. R., Fathimoghadam, F., Eftekharzadeh Mashhadi, I., Soghandi, L., and Bidkhori, H. R. (2011). Epidemiology of HTLV-1 in Neyshabour, Northeast of Iran. Iran. Red Crescent Med. J. 13, 424-427.

Hinuma, Y., Komoda, H., Chosa, T., Kondo, T., Kohakura, M., Takenaka, T., Kikuchi, M., Ichimaru, M., Yunoki, K., Sato, I., Matsuo, R., Takiuchi, Y., Uchino, H., and Hanaoka, M. (1982). Antibodies to adult Tcell leukemia-virus-associated antigen (ATLA) in sera from patients with ATL and controls in Japan: a nation-wide sero-epidemiologic study. Int. J. Cancer 29, 631-635.

Hinuma, Y., Nagata, K., Hanaoka, M., Nakai, M., Matsumoto, T., Kinoshita, D., Shirakawa, S., and Miyoshi, I. (1981). Adult T cell leukemia: antigen in an ATL cell line and detection of antibodies to the antigen in human sera. Proc. Natl. Acad. Sci. U.S.A. 78, 6476-6480.

Hisada, M., Okayama, A., Tachibana, N., Stuver, S. O., Spiegelman, D. L., Tsubouchi, H., and Mueller, N. E. (1998a). Predictors of level of circulating abnormal lymphocytes among human T-lymphotropic virus type I carriers in Japan. Int. J. Cancer 77, 188-192.

Hisada, M., Okayama, A., Shioiri, S, Spiegelman, D. L., Stuver, S. O., and Mueller, N. E. (1998b). Risk factors for adult T-cell leukemia among carriers of human Tlymphotropic virus type I. Blood 92, 3557-3561.

Hoshida, Y., Li, T., Dong, Z., Tomita, Y., Yamauchi, A., Hanai, J., and Aozasa, K. (2001). Lymphoproliferative disorders in renal transplant patients in Japan. Int. J. Cancer 91, 869-875.

Hunsmann, G., Bayer, H., Schneider, J., Schmitz, H., Kern, P., Dietrich, M., Büttner, D. W., Goudeau, A. M., Kulkarni, G., and Fleming, A. F. (1984). Antibodies to ATLV/HTLV-1 in Africa. Med. Microbiol. Immunol. 173, 167-170.

IARC. (1996). Human immunodeficiency viruses and human Tcell lymphotropic viruses. IARC Monogr. Eval. Carcinog. Risks Hum. $67,1-424$.

Ichimaru, M., Kinoshita, K., Kamihata, S., Ikeda, S., Yamada, Y., and Amagasaki, T. (1979). T-cell malignant lymphoma in Nagasaki district and its problems. Jpn. J. Clin. Oncol. 9, S337-S346.

Ikeda, N., Inoue, M., Iso, H., Ikeda, S., Satoh, T., Noda, M., Mizoue, T., Imano, H., Saito, E., Katanoda, K., Sobue, T., Tsugane, S., Naghavi, M., Ezzati, M., and Shibuya, K (2012). Adult mortality attributable to preventable risk factors for non-communicable diseases and injuries in Japan: a comparative risk assessment. PLoS Med. 9, e1001160. doi:10.1371/journal.pmed.1001160

Ikeda, S., Momita, S., Kinoshita K., Kamihira, S., Moriuchi, Y., Tsukasaki, K., Ito, M., Kanda, T., Moriuchi, R., and Nakamura, T. (1993). Clinical course of human Tlymphotropic virus type I carriers with molecularly detectable monoclonal proliferation of $\mathrm{T}$ lymphocytes: defining a low- and high-risk population. Blood 82, 2017.

Imaizumi, Y., Iwanaga, M., Tsukasaki, K., Hata, T., Tomonaga, M., and Ikeda, S. (2005). Natural course of HTLV-1 carriers with monoclonal proliferation of $\mathrm{T}$ lymphocytes ("pre-ATL") in a 20-year follow-up study. Blood 105, 903-904.

Ishida, T., Joh, T., Uike, N., Yamamoto, K., Utsunomiya, A., Yoshida, S., Saburi, Y., Miyamoto, T., Takemoto, S., Suzushima, H., Tsukasaki, K., Nosaka, K., Fujiwara, H., Ishitsuka, K., Inagaki, H., Ogura, M., Akinaga, S., Tomonaga, M., Tobinai, K., and Ueda, R. (2012). Defucosylated anti-CCR4 monoclonal antibody (KW-0761) for relapsed adult T-cell leukemia-lymphoma: a multicenter phase II study. J. Clin. Oncol. 30, 837-842.

Ishida, T., Utsunomiya, A., Iida, S., Inagaki, H., Takatsuka, Y., Kusumoto, S., Takeuchi, G., Shimizu, S., Ito, M., Komatsu, H., Wakita, A., Eimoto, T., Matsushima, K., and Ueda, R. (2003). Clinical significance of CCR4 expression in adult T-cell leukemia/lymphoma: its close association with skin involvement and unfavorable outcome. Clin. Cancer Res. 9, 3625-3634.

Iwanaga, M., Watanabe, T., Utsunomiya, A., Okayama, A., Uchimaru, K., Koh, K. R., Ogata, M., Kikuchi, H., Sagara, Y., Uozumi, K., Mochizuki, M., Tsukasaki, K., Saburi, Y., Yamamura, M., Tanaka, J., Moriuchi, Y., Hino, S., Kamihira, S., Yamaguchi, K., and Joint Study on Predisposing Factors of ATL Development investigators. (2010). Human T-cell leukemia virus type I (HTLV-1) proviral load and disease progression in asymptomatic HTLV-1 carriers: a nationwide prospective study in Japan. Blood 116, 1211-1219.

Kamihira, S., Atogami, S., Sohda, H., Momita, S., Yamada, Y., and Tomonaga, M. (1994). Significance of soluble interleukin-2 receptor levels for evaluation of the progression of adult T-cell leukemia. Cancer 73, 2753-2758.

Kamihira, S., Iwanaga, M., Doi, Y., Sasaki, D., Mori, S., Tsurda, K., Nagai, K., Uno, N., Hasegawa, H., Yanagihara, K., Morinaga, Y., Tsukasaki, K., and Taniguchi, H. (2012). Heterogeneity in clonal nature in the smoldering subtype of adult T-cell leukemia: continuity from carrier status to smoldering ATL. Int. J. Hematol. 95, 399-408.

Kawano, N., Shimoda, K., Ishikawa, F., Taketomi, A., Yoshizumi, T., Shimoda, S., Yoshida, S., Uozumi, K., Suzuki, S., Maehara, Y., and Harada, M. (2006). Adult T-cell leukemia development from a human T-cell leukemia virus type I carrier after a living-donor liver transplantation. Transplantation 82, 840-843.

Kchour, G., Makhoul, N. J., Mahmoudi, M., Kooshyar, M. M., Shirdel, A., Rastin, M., Rafatpanah, H., Tarhini, M., Zalloua, P. A., Hermine, O. Farid, R., and Bazarbachi, A. (2007). Zidovudine and interferon-alpha treatment induces a high response rate and reduces HTLV-1 proviral load and VEGF plasma levels in patients with adult T-cell leukemia from North East Iran. Leuk. Lymphoma 48, 330-336.

Kchour, G., Tarhini, M., Kooshyar, M. M., El Hajj, H., Wattel, E., Mahmoudi, M., Hatoum, H., Rahimi, H., Maleki, M., Rafatpanah, H., Rezaee, S. A., Yazdi, M. T., Shirdel, A., de Thé, H., Hermine, O., Farid, R. and Bazarbachi, A. (2009). Phase 2 study of the efficacy and safety of the combination of arsenic trioxide, interferon alpha, and zidovudine in newly diagnosed chronic adult T-cell leukemia/lymphoma (ATL). Blood 113, 6528-6532

Khameneh, Z. R., Baradaran, M., and Sepehrvand, N. (2008). Survey of the seroprovalence of HTLVI/II in hemodialysis patients and blood donors in Urmia. Saudi J. Kidney Dis. Transpl. 19, 838-841.

Koga, Y., Iwanaga, M., Soda, M., Inokuchi, N., Sasaki, D., Hasegawa, H., Yanagihara, K., Yamaguchi, K., Kamihira, S., and Yamada, Y. (2010). Trends in HTLV-1 prevalence and the incidence of adult Tcell leukemia/lymphoma (ATLL) in Nagasaki, Japan. J. Med. Virol. 82, 668-674. 
Kondo, T., Kono, H., Miyamoto, N., Yoshida, R., Toki, H., Matsumoto, I., Hara, M., Inoue, H., Inatsuki, A., Funatsu, T., Yamano, N., Bando, F., Iwao, E., Miyoshi, I., Hinuma, Y., and Hanaoka, M. (1989). Age- and sex-specific cumulative rate and risk of ATLL for HTLV-I carriers. Int. J. Cancer 43, 1061-1104.

Kondo, T., Kono, H., Nonaka, H., Miyamoto, N., Yoshida, R., Bando, F., Inoue, H., Miyoshi, I., Hinuma, Y., and Hanaoka, M. (1987). Risk of adult T-cell leukaemia/lymphoma in HTLV-I carriers. Lancet 2, 159.

Kondo, T., Nonaka, H., Miyamoto, N., Yoshida, R., Matsue, Y., Ohguchi, Y., Inouye, H., Komoda, H., Hinuma, Y., and Hanaoka, M. (1985). Incidence of adult T-cell leukemia-lymphoma and its familial clustering. Int. J. Cancer 35, 749-751.

Lee, C. W., Chang, M. C., Chang, Y. F., Hsieh, R. K., Lin, J., and Chen, K. S. (2010). Adult T-cell leukemia/lymphoma in Taiwan: an analysis of 17 patients and review of the literature. Asia Pac. J. Clin. Oncol. 6, 161-164.

Lee, M., Kim, B. K., Lee, H. B., Park, K. S., Suh, C., Lee, I. H., Bang, Y. I., Kim, S. T., Kim, N. K., Cha, C. Y., Moon, S. B., Cho, H. I., Lee, S. Y., and Takatsuki, K. (1987). Adult T-cell leukemia the first case in Republic of Korea. J. Kor. Med. Assoc. 30, 1146-1152.

Levine, P. H., Dosik, H., Joseph, E. M., Felton, S., Bertoni, M. A., Cervantes, J., Moulana, V., Miotti, A. B., Goberdhan, L. J., Lee, S. L., Daouad, A., DaCosta, M., Jaffe, E. S., Axiotis, C. A., Cleghorn, F. R., Kahn, A., and Welles, S. L. (1999). A study of adult T-cell leukemia/lymphoma incidence in central Brooklyn. Int. J. Cancer 80, 662-666.

Liang, R. (1994). HTLV-I associated adult T-cell leukaemia/lymphoma in Hong Kong. Am. J. Hematol. 45, 100-101.

Lymphoma Study Group of Japanese Pathologists. (2000). The World Health Organization classification of malignant lymphomas in Japan: incidence of recently recognized entities. Pathol. Int. 50, 696-702.

Manns, A., Miley, W. J., Wilks, R. J., Morgan, O. S., Hanchard, B., Wharfe, G., Cranston, B., Maloney, E., Welles, S. L., Blattner, W. A., and Waters, D. (1999). Quantitative proviral DNA and antibody levels in the natural history of HTLV-1 infection. J. Infect. Dis. 180, 1487-1493.

Manzari, V., Gradilone, A., Barillari, G., Zani, M., Collalti, E., Pandolfi, F., De Rossi, G., Liso, V., Babbo, P., and Robert-Guroff, M. (1985). HTLV-I is endemic in southern Italy: detection of the first infectious cluster in a white population. Int. J. Cancer 36, 557-559.

Marin, O., Hasui, K., Remondegui, C., Sato, E., Aye, M. M., Takenouchi, N., Izumo, S., and Tajima, K. (2002). Adult T-cell leukemia/lymphoma in Jujuy, north-west Argentina. Pathol. Int. 52, 348-357.

Meytes, D., Schochat, B., Lee, H., Nadel, G., Sidi, Y., Cerney, M., Swanson, P., Shaklai, M., Kilim, Y., Elgat, M., Chin, E., Danon, Y., and Rosenblatt, J. D. (1990). Serological and molecular survey for HTLV-I infection in a high-risk Middle Eastern group. Lancet 336, 1533-1535.

Miller, M., Achiron, A., Shaklai, M., Stark, P., Maayan, S., Hannig, H., Hunsmann, G., Bodemer, W., and Shohat, B. (1998). Ethnic cluster of HTLVI infection in Israel among the Mashhadi Jewish population. J. Med. Virol. 56, 269-274.

Mueller, N., Okayama, A., Stuver, S., and Tachibana, N. (1996). Findings from the Miyazaki Cohort Study. J. Acquir. Immune Defic. Syndr. Hum. Retrovirol. 13, S2-S7.

Murphy, E. L., Hanchard, B., Figueroa, J. P., Gibbs, W. N., Lofters, W. S., Campbell, M., Goedert, J. J., and Blattner, W. A. (1989). Modelling the risk of adult Tcell leukemia/lymphoma in persons infected with human $\mathrm{T}$ lymphotropic virus type I. Int. J. Cancer 43, 250-253.

Nakada, K., Yamaguchi, K., Furugen, S., Nakasone, T., Nakasone, K., Oshiro, Y., Kohakura, M., Hinuma, Y., Seiki, M., Yoshida, M., Matutes, E., Catovsky, D., Ishii, T., and Takatsuki, K. (1987). Monoclonal integration of HTLV-I proviral DNA in patients with strongyloidiasis. Int. J. Cancer 40, 145-148.

Ohshima, K., Suzumiya, J., and Kikuchi, M. (2002). The World Health Organization classification of malignant lymphoma: incidence and clinical prognosis in HTLV-1-endemic area of Fukuoka. Pathol. Int. 52, 1-12.

Okayama, A., Stuver, S., Matsuoka, M., Ishizaki, J., Tanaka, G., Kubuki, Y., Mueller, N., Hsieh, C. C., Tachibana, N., and Tsubouchi, H. (2004). Role of HTLV-1 proviral DNA load and clonality in the development of adult T-cell leukemia/lymphoma in asymptomatic carriers. Int. J. Cancer 110, 621-625.

Paun, L., Ispas, O., Del Mistro, A., and Chieco-Bianchi, L. (1994). HTLV-I in Romania. Eur. J. Haematol. 52, 117-118.
Plancoulaine, S., Buigues, R. P., Murphy, E. L., van Beveren, M., Pouliquen, J. F., Joubert, M., Rémy, F., Tuppin, P. Tortevoye, P., de Thé, G., Moreau, J. P., and Gessain, A. (1998). Demographic and familial characteristics of HTLV-1 infection among an isolated, highly endemic population of African origin in French Guiana. Int. J. Cancer 76, 331-336.

Plumelle, Y., Gonin, C., Edouard, A., Bucher, B. J., Thomas, L., Brebion, A., and Panelatti, G. (1997). Effect of strongyloides stercoralis infection and eosinophilia on age at onset and prognosis of adult T-cell leukemia. Am. J. Clin. Pathol. 107, 81-87.

Poiesz, B. J., Ruscetti, F. W., Gazdar, A. F. Bunn, P. A., Minna, J. D., and Gallo, R. C. (1980). Detection and isolation of type $\mathrm{C}$ retrovirus particles from fresh and cultured lymphocytes of a patient with cutaneous T-cell lymphoma. Proc. Natl. Acad. Sci. U.S.A. 77, 7415-7419.

Pombo de Oliveira, M. S., Loureiro, P., Bittencourt, A., Chiattone, C., Borducchi, D., De Carvalho, S. M., Barbosa, H. S., Rios, M., Sill, A., Cleghorn, F., and Blattner, W. (1999). Geographic diversity of adult t-cell leukemia/lymphoma in Brazil. The Brazilian ATLL Study Group. Int. J. Cancer 83, 291-298.

Pombo de Oliveira, M. S., Matutes, E., Schulz, T., Carvalho, S. M., Noronha, H., Reaves, J. D., Loureiro, P., MacHado, C., and Catovsky, D. (1995). T-cell malignancies in Brazil: clinico-pathological and molecular studies of HTLV-I positive and negative cases. Int. J. Cancer 60, 823-827.

Portal Site of Official Statistics of Japan. (2012). Portal Site of Official Statistics of Japan (e-Stat), Developed by Statistics Bureau, Ministry of Internal Affairs and Communications with the collaboration of Ministries and Agencies, and Managed by Incorporated Administrative Agency National Statistics Center. Available at: http://www. e-stat.go.jp/SG1/estat/GL08020101. do?_toGL08020101_\&tstatCode= 000001028897\&requestSender $=$ dsearch [In Japanese, accessed April 8, 2012]

Pouliquen, J. F., Hardy, L., Lavergne, A., Kafiludine, E., and Kazanji, M. (2004). High seroprevalence of human T-cell lymphotropic virus type 1 in blood donors in Guyana and molecular and phylogenetic analysis of new strains in the Guyana shelf (Guyana, Suriname, and French Guiana). J. Clin. Microbiol. 42, 2020-2026.
Proietti, F. A., Carneiro-Proietti, A. B., Catalan-Soares, B. C., and Murphy, E. L. (2005). Global epidemiology of HTLV-I infection and associated diseases. Oncogene 24, 6058-6068.

Rafatpanah, H., Hedayati-Moghaddam, M. R., Fathimoghadam, F., Bidkhori, H. R., Shamsian, S. K., Ahmadi, S., Sohgandi, L., Azarpazhooh, M. R., Rezaee, S. A., Farid, R., and Bazarbachi, A. (2011). High prevalence of HTLV-I infection in Mashhad, Northeast Iran: a populationbased seroepidemiology survey. J. Clin. Virol. 52, 172-176.

Safai, B., Huang, J. L., Boeri, E., Farid, R., Raafat, J., Schutzer, P., Ahkami, R., and Franchini, G. (1996). Prevalence of HTLV type I infection in Iran: a serological and genetic study. AIDS Res. Hum. Retroviruses 12, 1185-1190.

Sakuma, T., Satoh, T., Satodate, R., Madarame, T., Onodera, I., Suzuki, Z., and Itoh, C. (1988). Adult Tcell leukemia by probable horizontal transmission from husband to wife. Jpn. J. Clin. Oncol. 18, 75-79.

Satake, M., Yamaguchi, K., and Tadokoro, K. (2012). Current prevalence of HTLV-1 in Japan as determined by screening of blood donors. J. Med. Virol. 84, 327-335.

Satoh, M., Toma, H., Sugahara, K., Etoh, K., Shiroma, Y., Kiyuna, S., Takara, M., Matsuoka, M., Yamaguchi, K., Nakada, K., Fujita, K., Kojima, S., Hori, E., Tanaka, Y., Kamihira, S., Sato, Y., and Watanabe, T. (2002). Involvement of IL2/IL-2R system activation by parasite antigen in polyclonal expansion of CD4(+)25(+) HTLV-1-infected T-cells in human carriers of both HTLV-1 and S. stercoralis. Oncogene 21, 2466-2475.

Shimoyama, M. (1991). Diagnostic criteria and classification of clinical subtypes of adult T-cell leukaemialymphoma: a report from the Lymphoma Study Group (1984-87). Br. J. Haematol. 79, 428-437.

Shtalrid, M., Shvidel, L., Korenfeld, R., Duek, A., Landau, Z., and Berrebi, A. (2005). HTLV-1 associated adult T-cell leukemia/lymphoma in Israel: report of two patients of Romanian origin. Haematologica 90, ECR13.

Sidi, Y., Meytes, D., Shohat, B., Fenig, E., Weisbort, Y., Lee, H., Pinkhas, J., and Rosenblatt, J. D. (1990). Adult T-cell lymphoma in Israeli patients of Iranian origin. Cancer 65 , 590-593.

Sonoda, S., Li, H. C., and Tajima, K. (2011). Ethnoepidemiology of HTLV-1 related diseases: ethnic determinants of HTLV-1 
susceptibility and its worldwide dispersal. Cancer Sci. 102, 295-301.

Tachibana, N., Okayama, A., Ishihara, S., Shioiri, S., Murai, K., Tsuda, K., Goya, N., Matsuo, Y., Essex, M., Stuver, S., and Mueller, N. (1992). High HTLV-I proviral DNA level associated with abnormal lymphocytes in peripheral blood from asymptomatic carriers. Int. J. Cancer 51, 593-595.

Tajima, K. (1990). The 4th nationwide study of adult T-cell leukemia/lymphoma (ATL) in Japan: estimates of risk of ATL and its geographical and clinical features. The T- and B-cell Malignancy Study Group. Int. J. Cancer 45, 237-243.

Takatsuki, K., Uchiyama, J., Sagawa, K., and Yodoi, J. (1977). "Adult Tcell leukemia in Japan," in Topics in Hematology, eds S. Seno, F. Takaku, and S. Irino (Amsterdam: Excerpta Medica), 73-77.

Takezaki, T., Hirose, K., Hamajima, N., Kuroishi, T., and Tajima, K. (1997). Estimation of adult T-cell leukemia incidence in Kyushu District from vital statistics Japan between 1983 and 1982: comparison with a nationwide survey. Jpn. J. Clin. Oncol. 27, 140-145.

Talarmin, A., Vion, B., Ureta-Vidal, A, Du Fou, G., Marty, C., and Kazanji, M. (1999). First seroepidemiological study and phylogenetic characterization of human Tcell lymphotropic virus type I and II infection among Amerindians in French Guiana. J. Gen. Virol. 80, 3083-3088.

The T- and B-Cell Malignancy Study Group. (1981). Statistical analysis of immunologic, clinical and histopathologic data on lymphoid malignancies in Japan. Jpn. J. Clin. Oncol. 11, 15-38.

The T- and B-Cell Malignancy Study Group. (1985). Statistical analyses of clinico-pathological, virological and epidemiological data on lymphoid malignancies with special reference to adult T-cell leukemia/lymphoma: a report of the second nationwide study of Japan. Jpn. J. Clin. Oncol. 15, 517-535.
Tian, Y., Kobayashi, S., Ohno, N., Isobe, M., Tsuda, M., Zaike, Y., Watanabe, N., Tani, K., Tojo, A., and Uchimaru, K. (2011). Leukemic T cells are specifically enriched in a unique CD3(dim) CD7(low) subpopulation of CD4(+) $\mathrm{T}$ cells in acute-type adult T-cell leukemia. Cancer Sci. 102, 569-577.

Tokudome, S., Tokunaga, O., Shimamoto, Y., Miyamoto, Y., Sumida, I., Kikuchi, M., Takeshita, M., Ikeda, T., Fujiwara, K., Yoshihara, M., Yanagawa, T., and Nishizumi, M. (1989). Incidence of adult T-cell leukemia/lymphoma among human T-lymphotropic virus type I carriers in Saga, Japan. Cancer Res. 49, 226-228.

Tsuji, T., Sugahara, K., Tsuruda, K., Uemura, A., Harasawa, H., Hasegawa, H., Hamaguchi, Y., Tomonaga, M., Yamada, Y., and Kamihira, S. (2004). Clinical and oncologic implications in epigenetic down-regulation of CD26/dipeptidyl peptidase IV in adult T-cell leukemia cells. Int. J. Hematol. 80, 254-260.

Tuppin, P., Lepère, J. F., Carles, G., UretaVidal, A., Gérard, Y., Peneau, C., Tortevoye, P., de Thé, G., Moreau, J. P., and Gessain, A. (1995). Risk factors for maternal HTLV-I infection in French Guiana: high HTLVI prevalence in the Noir Marron population. J. Acquir. Immune Defic. Syndr. Hum. Retrovirol. 8, 420-425.

Uchiyama, T., Yodoi, J., Sagawa, K., Takatsuki, K., and Uchino, $\mathrm{H}$. (1977). Adult T-cell leukemia: clinical and hematologic features of 16 cases. Blood 50, 481-492.

Uno, H., Kawano, K., Matsuoka, H., and Tsuda, K. (1988). HLA and adult T-cell leukaemia: HLA-linked genes controlling susceptibility to human T-cell leukaemia vims type I. Clin. Exp. Immunol. 71, 211-215.

Veelken, H., Kohler, G., Schneider, J., Dierbach, H., Mertelsmann, R., Schaefer, H. E., and Lubbert, M. (1996). HTLV-I-associated adult T cell leukemia/lymphoma in two patients from Bucharest, Romania. Leukemia 10, 1366-1369.
Yamada, Y., Atogami, S., Hasegawa, H., Kamihira, S., Soda, M., Satake, M., and Yamaguchi, K. (2011). Nationwide survey of adult Tcell leukemia/lymphoma (ATL) in Japan. Rinsho Ketsueki 52, 1765-1771.

Yamaguchi, K., Kiyokawa, T., Nakada, K., Yul, L. S., Asou, N., Ishii, T., Sanada, I., Seiki, M., Yoshida, M., and Matutes, E. (1988). Polyclonal integration of HTLV-I proviral DNA in lymphocytes from HTLV-I seropositive individuals: an intermediate state between the healthy carrier state and smouldering ATL. Br. J. Haematol. 68, 169-174.

Yamaguchi, K., Matutes, E., Catovsky, D., Galton, D. A., Nakada, K., and Takatsuki, K. (1987). Strongyloides stercoralis as candidate co-factor for HTLV-I-induced leukaemogenesis. Lancet 2, 94-95.

Yamaguchi, K., Seiki, M., Yoshida, M., Nishimura, H., Kawano, F., and Takatsuki, K. (1984). The detection of human $\mathrm{T}$ cell leukemia virus proviral DNA and its application for classification and diagnosis of T cell malignancy. Blood 63, 1235-1240.

Yamaguchi, K., Uozumi, K., Taguchi, H., Kikuch, H, Okayama, A., Kamihira, S., Hino, S., Nosaka, K., and Watanabe, T. (2007). Nationwide Cohort Study of HTLV-1 Carriers in Japan: Joint Study on Predisposing Factors of ATL Development (JSPFAD) [Abstract O-23]. AIDS Res. Hum. Retroviruses 23, 581-600.

Yamamoto, J. F., and Goodman, M. T. (2008). Patterns of leukemia incidence in the United States by subtype and demographic characteristics, 1997-2002. Cancer Causes Control 19, 379-390.

Yashiki, S., Fujiyoshi, T., Arima, N., Osame, M., Yoshinaga, M., Nagata, Y., Tara, M., Nomura, K. Utsunomiya, A., Hanada, S., Tajima, K., and Sonoda, S. (2001). HLA$\mathrm{A} * 26$, HLA-B $* 4002$, HLAB $* 4006$, and HLA-B $* 4801$ alleles predispose to adult $\mathrm{T}$ cell leukemia: the limited recognition of HTLV type 1 tax peptide anchor motifs and epitopes to generate anti-HTLV type 1 tax CD8(+) cytotoxic T lymphocytes. AIDS Res. Hum. Retroviruses 17, 1047-1061.

Yoshida, M., Miyoshi, I., and Hinuma, Y. (1982). Isolation and characterization of retrovirus from cell lines of human adult T-cell leukemia and its implication in the disease. Proc. Natl. Acad. Sci. U.S.A. 79, 2031-2035.

Yoshizumi, T., Shirabe, K., Ikegami, T., Kayashima, H., Yamashita, N., Morita, K., Masuda, T., Hashimoto, N., Taketomi, A., Soejima, Y., and Maehara, Y. (2012). Impact of human $\mathrm{T}$ cell leukemia virus type 1 in living donor liver transplantation. Am. J. Transplant. 12, 1479-1485.

Zhuo, J., Yang, T., Zeng, Y., and Lu, L. (1995). Epidemiology of antihuman T-cell leukemia virus type I antibody and characteristics of adult T-cell leukemia in China. Chin. Med. J. 108, 902-906.

Conflict of Interest Statement: The authors declare that the research was conducted in the absence of any commercial or financial relationships that could be construed as a potential conflict of interest.

Received: 02 May 2012; accepted: 20 August 2012; published online: 10 September 2012.

Citation: Iwanaga $M$, Watanabe $T$ and Yamaguchi K (2012) Adult T-cell leukemia: a review of epidemiological evidence. Front. Microbio. 3:322. doi: 10.3389/fmicb.2012.00322

This article was submitted to Frontiers in Virology, a specialty of Frontiers in Microbiology.

Copyright (C) 2012 Iwanaga, Watanabe and Yamaguchi. This is an openaccess article distributed under the terms of the Creative Commons Attribution License, which permits use, distribution and reproduction in other forums, provided the original authors and source are credited and subject to any copyright notices concerning any third-party graphics etc. 